\title{
International communication dynamics of American intervention efforts to democratize in the arab spring through forward strategy for freedom in the middle east
}

\author{
Fika Nurislamia ${ }^{a, 1, *}$, E.J Syamsy Asriya ${ }^{\mathrm{b}, 2}$ \\ ${ }^{a}$ Universitas Muhammadiyah Yogyakarta, Jl. Brawijaya, Kasihan, Bantul 55183, Indonesia \\ ${ }^{\mathrm{b}}$ Universitas Muhammadiyah Yogyakarta, Jl. Brawijaya, Kasihan, Bantul 55183, Indonesia \\ ${ }^{1}$ nurislamiaf@ gmail.com*; ${ }^{2}$ Ejsyamsyaaa@ gmail.com; \\ * corresponding author
}

\section{ARTICLE INFO}

Article history

Received 2019-06-23

Revised 2019-08-25

Accepted 2019-09-19

Keywords

Arab Spring

Missle East

Democracy

Strategy

United States

\section{ABSTRACT}

This papera aims to describe how international communication dynamics of America to response of Arab Spring. Arab Spring is an event that shocked the world when the Middle East flared up. The demonstrators took to the streets to demand an authoritarian regime downgrade and replace it with democracy. The democratization process that took place in the Middle East was in the world spotlight. America is considered a country that intervenes so that democratization can be realized in the Middle East. This is supported by various American interests in the Middle East. By using research library data search methods, the authors get the results of the form of intervention carried out by America to realize democratization in the Middle East.

This is an open access article under the CC-BY-SA license.

\section{Introduction}

On December 17 2010, was the beginning of the upheaval in the Middle East. The self-burning carried out by Mohammer Bouazizi succeeded in burning anger from Tunisians who had been confined by an authoritarian government. The demonstrations that happened for months demanding the demise of the long-held regime. The protest which took place in Tunisia then spread to other Middle East countries. Under the pretext of having a similar condition, because they lived on a corrupt government regime, the demonstrators made a massive revolution that not only replaced the ruling leaders but also replaced the government system that was originally authoritarian into democracy. Democracy is a new thing for the Middle East. It is not easy to know about democracy and democracy. The Middle East is an Islamic State, which has been talked about inappropriately when using democratic understandings. This is because democracy is a product of western countries which many consider contrary to Islamic thought. In its development, democracy has often been linked to America as the most democratic country in the world. In addition, America has ambitions to spread democracy to all countries in the world. In this paper, the author tries to provide an American intervention in the Arab Spring conflict, as well as what American interests are in the Arab Spring conflict. 


\section{Theorical Framework}

\subsection{Arab Spring}

The Arab Spring is a term that has shocked the world recently. The political upheaval that occurred in the Middle East in 2010 to 2011 even until 2013 was the heaviest political upheaval experienced by Middle Eastern countries. One by one the leaders of countries in the Middle East was fall such as the fall of leaves during the spring causing this political upheaval, so its called the Arab Spring [1]. The form of this Arab Spring is demonstrations, anti-government campaigns and the using of social media to bring down the government [2]. The aim of Arab Spring is to overthrow the Middle East authoritarian regimes and return power to the people.

The Arab Spring incident began in Tunisia, when one 26-year-old Tunisian fruit seller named Mohamed Bouazizi was determined to burn himself because he was mistreated by officers who collected his fines. Not accepting the arbitrary action taken by the officer, Bouazizi then reported to the local government officials. But what Bouazizi received was nil, his complaint was not responded. Bouazizi's disappointment ended tragically, then he set himself on fire as a form of protest.

This provoked the emotions of the Tunisian people and there was a massive demonstration throughout Tunisia. The people shouted their frustration and anger to the government because of the decreasingly economic conditions. The increasing of Tunisia's deteriorating economy makes unemployment and poverty increase. Coupled with the authoritarian system of government in Tunisia worsened the situation. The people demanded that President Ben Ali, who was in power for 33 years be forced to retire from his position [3]. The election in Tunisia on November 14, 2011 was the first election after the implementation of democracy in this country. This election was followed by $4,308,888$ of $8,289,924$ voters [4].

Incident that happened in Tunisia then spread into other Arab's countries. Libya, a country directly adjacent to Tunisia, is a country in the Middle East which is carrying out further action. The civil war that took place in Libya originated from a demonstration held in Benghazi in 2011. The aim of the demonstration was to demand the retire of Muammar Khaddafi from his position as Libyan leader. The war starts from repressive actions by the government in overcoming protesters then the protesters escalate into a civil war and a rebellion. This war resulted thousands of Libyans fleeing to the safer places, while the two armed groups attacked each other with rifles, anti-aircraft guns and rockets. The anti-government protest movement then succeeded in forcing Gaddafi out of hiding to finally die at the hands of the opposition in 2012 [5]. Under the National Transitional Council, Libya held a Parliamentary Election held in July 2012 [5]. The Libyan civil war is reportedly one of the socio-political revolutions that took place in the Arabian Peninsula together with Tunisia and Egypt.

Revolution also happened in Morocco. Morocco democratized with multi-party elections on November 27, 2011. This happened because of fears of the King of Morocco, King Muhammad IV towards Morocco which will get the same wave of action like Tunisia and Egypt. The democratization carried out by Morocco was also followed by Algeria and Jordan. The two countries followed Morocco's footsteps to prevent unintended incidents happened. In contrast to Bahrain, where the majority Syiah group has to face Sunni minority groups assisted by Saudi Arabia [6].

The Arab Spring wave also spread to Yemen, where the people demanded President Abdullah Salih to step down from his position. The incidents that occurred in Tunisia and Egypt repeated in this country, President Abdullah stepped down and had to leave his palace after a massive demonstration by the people on April 23 in exchange for legal immunity. But President Abdullah denied this agreement so that the rebellion in Yemen took place again [7].

The impact of the Arab Spring is still happening in Syria until now. Opposition groups demanded President Bashar Assad to step down from his position. Minority groups under Assad must fight majority groups dominated by Sunnis. Because of the president's supporter group are a minority, this group is asking for another help from outside such as Iran, Hezbollah and also Russia to be able to block the power of the majority group. In February 2011, social media sites inside and outside Syria called for massive demonstrations to demanding the government to carry out reforms. Reform supporters outside Syria sent satellite modems, cellular phones and other social media tools to support this [8]. 
December 17, 2010 is a day that the burning action of Bouazizi and its considered as the beginning of the Arab Spring. Seeing the dynamics that occur in the Middle East, things that should be highlighted is an authoritarian and mass government. The masses felt intimidated by an authoritarian government and they were driven to get out from the government's arbitrariness. The success that took place in Tunisia became a benchmark for neighboring countries to carry out similar incidents.

Most of the demands in countries experiencing the Arab Spring are democracy. Democracy is an oasis amid the authoritarian desert of the Middle East. The community demands a change of leader which is conducted regularly. They expect that their new leaders can lead properly and receive aspirations and input from their people. Besides because of the understanding, the thing that unites the demonstrators in suffering experienced is because of the religion adopted. Understanding of suffering and religion can reduce the impact of losses and risks arising from the demonstration. The new question that arises in everyone's mind is, does democratization in the Middle East have no interference from the most democratic country in the world and the superpower, the United States?.

\subsection{Islam and Democracy}

The Middle East region is a strategic region. Besides having a past culture that is interesting to learn, the Middle East also has abundant natural resource potential. The Mineral content such as copper, coal and iron is an attraction for other countries. The valuable assets of the Middle East increased after the discovery of petroleum in the 1930s, especially around the bay areas [9]. This is certainly the target of intervention from various developed countries, including America. Various ways have been taken to carry out these interventions, including demonstrating the democracy as a perfect form of government system.

The fluctuation of the Arab Spring has proven that democracy began to dominate the Middle East. The democratization that occurred in the Middle East is one form of intervention carried out by America. Democratization in the Middle East was previously regarded as an impossibility by seeing the religion adhered to by Middle East countries which is Islam. Islam and democracy were considered as two things that cannot go hand in hand. The development of the idea that leaders are an extension of God and who are elected leaders is a messenger of God making countries in the Middle East have a monarchical system of government.

Islamism has occurred in the Middle East. Where Islam is not only a religion that is embraced, but has entered into politics. Politics of Islam makes Islam as an ideology rather than as a religion or belief. In this conflict in the Middle East, the Reformation Groups used Islam to bring together individuals who were often involved in the Islamic movement, integrating it into a new social movement for change in the presence of democracy, freedom and social justice [10].

However, the Arab Spring happened not because of religion. Arab Spring occurs because of pure economic inequality and lack of welfare in society. Too arrogant leaders and high-class dictators lead Middle Eastern countries, so the people of the Middle East feel it's time for them to move and call for resistance. The similarity of religion is the second thing that is the reason for these demonstrators to unite. Although we basically see Islam as the first reason for the demonstrators gather and dare to call for a revolution in the Middle East.

Therefore, how can democracy develop in an Islamic country like in the Middle East countries? Samuel P. Huntington said that Islam limits democratization. Religion can be a motivation for an individual's life. For Muslims, Islam is a way of life, moral philosophy, belief system or spiritual order. Islam is the most complete guideline for adherents [11]. Islam runs in the Middle East in covering religious practices and social life. In both, Islam is indistinguishable.

In the life of an Ideal Islamic state, political activities must be approved by God. As mentioned earlier, Religion governs all forms of life including political life. Political decisions are formed not by the will of the autocracy or the political elite in power, but it is God's law that regulates all. The state and government must guarantee that all Muslims can worship well. That is what is called the Ideal Islamic State.

In this conflict in the Middle East, democracy is considered a bright spot where people want power in their hands. Claims about the Islamic State and democracy are two things that cannot possibly be damaged here. Since democracy can improve welfare and eliminate inequality that has 
been created by these authoritarian leaders. It is a challenge to create democracy in a country that has never been acquainted with democracy before. Democracy is a government system where the highest power is in the hands of the people, carried out directly by the people or by representatives of people who elected in general elections. Democracy developed rapidly during the Renaissance. At this time the community held a direct position in the government. According to Abraham Lincoln, democracy requires direct participation from the people [12]. Democracy is considered to be an ideal system that can avoid conflict with one another, democracies tend to go to war with each other [13].

One element of enforcing democracy is the civil society, which is a society that is open and free from the influence and pressure of other countries. Civil society is an active society as a control of government performance [14].In Islam, democracy does not conflict with its principles and teachings. Democracy conducts the electoral process by involving many people. Islam does not limit freedom of speech, and express opinions as long as they are in accordance with the applicable norms and adab. Democracy is the embodiment of social life in increasingly diverse Muslim countries so that the search for theology of pluralism becomes inevitable [15].

\section{Method}

This paper focuses on the study of literature. In this study, the author read works related to the theme had raised. The type of this research is descriptive research which used literature to obtain data and then analyzed based on the theoretical basis used to frame the data analyzed. The theoretical foundation used is an intervention in the form of democratization.

\section{Results and Discussion}

The United States is the most democratic country in the world. His involvement in echoing the name of democracy in the world is no doubt. In fact, the American Foreign Policy issued a strategy known as the "Forward Strategy of Freedom in the Middle East" as an answer to the existence of American involvement in the democratization that occurred in the Middle East. American hegemony towards the Middle East has begun since the end of the cold war between the western bloc and the eastern bloc. The success of the western bloc has made America strive to stem the spread of communism throughout the world, including in the Middle East. In addition to stopping communism, America also spreads the notion of democracy that is recognized as the best government system [16]. To strengthen its strength, America in the Regan period had many relations with countries such as Israel, Jordan and Saudi Arabia [17]

In a speech that presented in 2003, President Bush said that democracy and Islam could walk side by side. This is evidenced by the success of democracy in Turkey and also Indonesia. America has spread democracy to an unprecedented place, and President Bush believes that democracy will enhance peace and security for his country and the Middle East. His speech also explained about the Middle East Partnership Initiative. Namely set the first initiative to support the effort of political reform and economic development through women and youth [18].

The speech published in 2003 could be called as the evidence of America's involvement in the Arab Spring that occurred in the Middle East in 2010 to 2011. The American ambition to democratize the countries that have not implemented democracy is very visible. This is because America can freely cooperate and establish good relations with a democratic country so that it can benefit America itself. America forms the Greater Middle East Initiative to launch a process of democratization in the Middle East. However, according to Eddie J. Girdner GMEI was not formed to facilitate freedom in the Middle East, but to make it easier for America to gain its interests [19]. GMEI is nothing but a tool for the expansion and consolidation of neoliberalism in the Middle East and also Indonesia [20].

According to J.G Starke, intervention is an act of propaganda which carried out by a country with the aim of a revolution or war in another country. Then the understanding of intervention according to Black's Law Dictionary, one nation's interference by force, or threat of force, in another nation's internal affair or in question arising between other nations or interference of one country with violence, or threats of violence, in internal affairs of other countries or in questions that arise between other countries. Based on the two meanings above, it could be concluded that intervention 
is one form of control toward other countries by interfering in the form of violence or statements that arise between other countries.

The form of intervention carried out by America is to interfere domestic politics in several countries in the Middle East. The exoticism of the Middle East is an attraction for America to control its natural resources. Abundant petroleum is the main goal of America by intervening the Middle East. Evidenced by the formation of puppet countries in Iraq (Sihbudi, 2007). This aim to control of petroleum in Iraq. In addition to meddling in the Middle East's domestic politics, the United States also gave a statement delivered by President Bush about disarmament in Iraq by asking the United Nations to fulfil its charter and asking the International Atomic Energy Agency to track and control nuclear bombs in the world, particularly in Iraq. Moreover, the form of American intervention was also felt in Iran. Still on President Bush's speech in State of the Union, America continues to pay attention to the Iranian government which oppresses the people. In addition, America is also seeking weapons of mass destruction in Iran and eradicating the terror that has taken place in the country. President Bush also supports Iranians who risk their lives and continue to be intimidated for calling the democracy in Iran [21]

Having previously meddled many countries in Latin America under the pretext of democracy [22], American interests in intervening the Middle East have been carried out since the 1970s. Democratization of the Middle East is considered as a way of American to intervening the government then America can more easily get the hearts of the people who are in the worst condition in an authoritarian government. The American foreign policy issued by President Bush's speech was an emphasis on Middle Eastern countries which were considered as terrorist nests based on the attacks of September 11, 2001. The democratization that occurred in the Arab Spring on 2010 to 2011 was an extension of American Foreign Policy Strategy Forwarder for Freedom in the Middle East. Middle East democratization is intended not solely to give freedom to Middle Eastern society, but also to minimize threats toward America which are no longer States but sub-State actors involved in terrorist activities. These foreign policy planners believe that terrorist perpetrators on September 11, 2001 and many incidents related to other terrorist activities came from countries that have not implemented democracy [23]. To facilitate its interests, America obtained permits to permanently deploy troops in the Middle East by establishing cooperation with several regional areas [24].

In the Egyptian coup, America blamed the Mursi government for not improving the welfare of its people. The civil conflict that occurred in Egypt was also caused by pro-government people. From 2002 to 2006, the Bush regime used public statements, personally urged and described aid programs to encourage the Mubarak government towards meaningful political reforms [25]. America supports democratization in Middle Eastern countries like Syria by supporting opposition with Saudi Arabia. This was evidenced by the announcement that America would send reinforcements to opposition groups [26]. Democracy in Lebanon is of particular concern to America. This is because American interests are to guarantee Israeli security. Given several times to the Hezbollah group threatened Israel through UAV attacks [27]. In addition, America also stressed the importance of democracy in Lebanon, considering that at the practical level leaders in Lebanon must be balanced between Christianity and Islam [28]. In addition, the rise of the Islamic political movement in Syria is also a threat to America. On this basis, America put it in the list of terrorists [29].

Democracy is considered as one of the forms of intervention that has become the ideal of America to subjugate Middle East countries. America argues the democratization in the Middle East as a way out of all the problems and crises that occur there. In addition, democracy is also expected to erase the anti-American sentiment that has spread throughout the Middle East region.

\section{Conclusion}

The Middle East region is an exotic area that holds a lot of charm for the surrounding countries. The availability of abundant resources is the main thing that makes the Middle East as prima donna. The Arab Spring tragedy became the initial process of democratization in the Middle East. This is inseparable from American intervention to more easily control the Middle East countries and to achieve their own national interests. The power of authoritarian governments in the Middle East fell one by one like the leaves falling in the 
spring. Islam and democracy are expected to go hand in hand to create peace in the Middle East.

The Internet effect in the dynamics occurring in Arab Spring is also worthy to get serious highlights, The internet is capable of affecting human behaviour [30], as the internet does have the power to do great social movements [31]. But the most important thing for us to realize is the Internet has the opportunity to awaken democracy in a country [32].

\section{References}

[1] H. Wangke, “'Arab Spring' Dan Perebutan Pengaruh di Suriah,” J. Polit., vol. Vol 3, pp. 001-161, 2012.

[2] A. V. Korotayev and J. V. Zinkina, "Egyptian revolution: a demographic structural analysis," Entelequia - Rev. Interdiscip., vol. 13, no. primavera 2011, pp. 139-170, 2011.

[3] H. Sahrasad, "ARAB SPRING: PERUBAHAN REZIM DAN TEGANGAN HUBUNGAN AS DUNIA ARAB REFLEKSI SOSIO-HISTORIS,” J. C. Vol. VI Nomor 1, Ed. Januari - Juni 2013, vol. VI, pp. 36-54, 2013.

[4] B. Juliandi, "Wakaf dan Politik di Tunisia," AHKAM Jurnal Ilmu Syariah, vol. 15, no. 2, pp. 137$144,2016$.

[5] M. Fakhry Ghafur, "Agama Dan Demokrasi : Munculnya Kekuatan Politik Islam Di Tunisia, Mesir Dan Libya 1 Religion and Democracy: the Emergence of the Power of Political Islam in Tunisia, Egypt and Libya," J. Penelit. Polit., vol. 11, no. 2, pp. 85-100, 2014.

[6] M. Muttaqien, “Arab Spring: Dimensi Domestik, Regional dan Global,” J. Glob. Strateg., vol. 9, no. 2, p. 262, 2018.

[7] S. Jatmika, "The Arab Spring 2010: Puncak Gunung Es Krisis Politik di Kawasan Timur Tengah," J. Hub. Int., vol. 2, no. 2, pp. 157-166, 2016.

[8] U. N. Yogyakarta, "Konflik di Suriah pada Masa Bashar al- Assad Pada Tahun 2011-2015," konflik di suriah, 2016.

[9] M. Konflik, T. Tengah, T. G. Politik, J. Politik, and P. Volume, "Memetakan Konflik di Timur Tengah (Tinjauan Geografi Politik) Jurnal Politik Profetik Volume 1 Nomor1 Tahun 2013," vol. 1, 2013.

[10] S. E. Yasmine, "Arab Spring: Islam dalam gerakan sosial dan demokrasi Timur Tengah Arab Spring: Islam within social movement and democracy in the Middle," Masyarakat, Kebud. dan Polit., vol. 28, no. 2, pp. 110-112, 2015.

[11] B. J. Cook and M. Stathis, "Democracy and Islam: promises and perils for the Arab Spring protests," J. Glob. Responsib., vol. 3, no. 2, pp. 175-186, 2012.

[12] K. M. Hakiki, "Islam dan Demokrasi: Pandangan Intelektual Muslim dan Penerapannya di Indonesia," Wawasan J. Ilm. Agama dan Sos. Budaya, vol. 1, no. 1, pp. 1-17, 2016.

[13] E. D. Mansfield and B. M. Pollins, "Interdependence and Conflict: An Introduction," Econ. Interdepend. Int. Confl. New Perspect. an Endur. Debate, pp. 1-28, 2003.

[14] A. Rangkuti, "Demokrasi dalam Pandangan Islam dan Barat," J. Ilm. Penegakan Huk., vol. 5, no. 2, pp. 49-59, 2019.

[15] I. IRAWAN, "Al-Tawassut waal-I'tidal: Menjawab Tantangan Liberalisme dan Konservatisme Islam,” Afkaruna, vol. 14, no. 1, pp. 49-74, 2019.

[16] L. W. P. T. Utama Firmanda, "Hegemoni Amerika Serikat Terhadap Arah Kebijakan Arab Saudi dalam Konflik Yaman Pasca Arab Spring 2011-2017,’ J. ICMES, vol. 1, no. 1, pp. 25-44, 2017.

[17] A. Setiawan, "Diplomatic Dilemma dan Standar Ganda Politik Amerika Serikat terhadap Konflik SipilMiliter Mesir Tahun 2013," JOM FISIP, vol. 2, no. SGEM2016 Conference Proceedings, ISBN 978-619-7105-16-2 / ISSN 1314-2704, pp. 1-39, 2013.

[18] N. Endowment, D. Address, and M. East, "National Endowment for Democracy Address on the Middle East,” Chamb. Commer., no. November, pp. 1-8, 2003. 
[19] E. J. Girdner, “Operation Iraqi Freedom: Invasion, Occupation and Consolidation of US Hegemony in Iraq,” Punjab J. Polit., vol. 28 (2), pp. 1-31, 2004.

[20] E. J. GIRDNER, "the Greater Middle East Initiative: Regime Change, Neoliberalism and Us Global Hegemony,” Milletleraras, pp. 001-035, 2005.

[21] the washinton post, "Text of President Bush's 2003 State of the Union Address," Washinton DC, 2003.

[22] K. Jaya, "Venezuela's communication dynamics in rejection of humanitarian assistance from United States of America," Int. J. Commun. Soc., vol. 1, no. 1, pp. 26-33, 2019.

[23] D. Neep, "Dilemmas of Democratization in the Middle East," Middle East Policy, vol. VOL. XI, N, pp. 73-84, 2003.

[24] D. Darwis, "Kerangka Kebijakan Luar Negeri Amerika Serikat Terhadap Timur Tengah Pasca Arab Spring,” 23 Juni 2015, 2015.

[25] M. Dunne, "The baby, the bathwater, and the freedom agenda in the Middle East," Wash. Q., vol. 32, no. 1, pp. 129-141, 2009.

[26] B. W. Adi, "Peningkatan Keterlibatan Amerika Serikat di Era Kepemimpinan Obama Dalam Konflik Suriah,” Repos. umy, pp. 1-24, 2018.

[27] A. H. Cordesman, "Lebanese Security and the Hezbollah,” Cent. Strateg. Int. Stud., vol. 1, no. 202, pp. 1-38, 2006.

[28] M. East and J. Choucair, "Lebanon: Finding a Path from Deadlock to Democracy," Carnegie Endow. Int. Peace, no. 64, pp. 1-20, 2006.

[29] D. Darwis, "Kebangkitan Gerakan Politik Islam dalam Pergolakan Suriah Menurut Persepsi Amerika Serikay ( Studi Kasus : Persepsi AS terhadap Jabhat Al-Nusrah di Suriah ),” 2003.

[30] F. F. Lotan, "Making a positive internet through Socmed Agawe Guyub," Int. J. Commun. Soc., vol. 1, no. 1, pp. 9-16, 2019.

[31] D. Fadillah, L. Zhenglin, and D. Hao, "Social Media and General Elections in Malaysia 2018 and Indonesia 2019,” J. Komun. ISKI, vol. 4, no. 1, pp. 1-8, 2019.

[32] Uspal Jandevi, "New media for increasing political participation in Indonesia," Int. J. Commun. Soc., vol. 1, no. 1, pp. 1-8, 2019. 